\title{
Assessment of tree diversity in distinctive deciduous forests of Suruli falls, Southern Western Ghats
}

\section{J. Naveenkumar \\ Department of Ecology and Environmental Sciences, Pondicherry University, Puducherry-} 605014, India

SM. Sundarapandian*

Department of Ecology and Environmental Sciences, Pondicherry University, Puducherry 605014, India

*Corresponding author. E-mail: smspandian65@gmail.com

\begin{abstract}
A quantitative inventory was conducted in two distinctive tropical deciduous forests at Suruli falls forest of southern Western Ghats. Two one-hectare plots were established and all trees $>10 \mathrm{~cm}$ DBH measured. Species richness, density, family importance value (FIV) and importance value index (IVI) were calculated and the results varied among the two sites. A total of 777 stems and 52 species were documented in both the sites and moist deciduous forest (MDF) had maximum number species richness and density than dry deciduous forest (DDF). The basal area was higher in MDF (502 stems/ha and 16.52 $\mathrm{m}^{2} / \mathrm{ha}$ ) than in DDF (275 stems/ha and $7.23 \mathrm{~m}^{2} / \mathrm{ha}$ ). However, Shannon and evenness indices showed a negative trend (DDF- 2.62, 0.41 and MDF- 2.37, 0.27). Diameter classwise distribution of trees showed reverse ' $\mathrm{J}$ shaped' curve in both the forest types. Pterocarpus marsupium was the mono-dominant species holding one-third of the IVI (113), $27 \%$ of the stem density and $30 \%$ of the total basal area. DDF site is suspected to recurrence of annual fire. Anogeissus latifolia and Strychnos potatorum were the fire-tolerant species only found in lower diameter class. The maximum species shared contiguous distribution in the deciduous forests. The observed variations in the tree community between the two deciduous forest sites are possibly due to variations in altitude, rainfall, temperature, past disturbance, fire and edaphic characteristics.
\end{abstract}

Keywords: Tropical forest, Species richness, Forest fire, Distribution, Mono-dominance

\section{INTRODUCTION}

Tropical forests are the richest and complex biomes on the earth's surface and it is providing $50 \%$ of the world life form (Wilson, 1988) that includes $96 \%$ of tree species richness (Poorter et al., 2015). However, these forest ecosystems are losing their ability due to increasing biotic infestation such as anthropogenic perturbations and cattle grazing (Sundarapandian and Swamy, 2000). Tropical forest of Asia, mainly those of Western and Eastern Ghats of southern India are declining at an alarming rate because of pertaining anthropogenic pressure which is either being replaced by inferior species or change in land use pattern (Parthasarathy, 1999). The disappearance of these tropical forest ecosystem comes at a time when information about their structure and dynamics remains inadequate (Hubbell and Foster, 1992). Anthropogenic intervene in this forests is still past and pre-history (Parthasarthy, 1999). Documentation and impacts on genetic tree diversity are quite difficult as quantitative information is lacking (Ledig, 1992). So the inventory of tree

\section{Article Info}

DOI: 10.31018/jans.v10i4.1879 Received: August 29, 2018 Revised: September 14, 2018 Accepted: October 4, 2018

\section{How to Cite}

Naveenkumar, J. and Sundarapandian, SM. (2018). Assessment of tree diversity in distinctive deciduous forests of Suruli falls, Southern Western Ghats. Journal of Applied and Natural Science, 10 (4): $1085-1093$ species is a vital aspect for the conservation of forest as they are the essential structural characteristics of the forest (Aye et al., 2014).

India is one amongst the tropical countries and concerning $54 \%$ and $37 \%$ of Indian tropical forests that are classified as dry and moist deciduous forests respectively (Kaul and Sharma, 1971; Krishnamurthy et al., 2010). The Western Ghats are chain hills on the West Coast of India covering around 1500 kilometer of the geographical area which passes through the states of Goa, Maharashtra, Karnataka, Tamil Nadu and Kerala with (Nair and Daniel, 1986; Karuppusamy and Ravichandran, 2016). The environmental condition and elevation gradient has resulted in an exceedingly different form of vegetation types, viz., evergreen, semi-evergreen, moist deciduous and dry deciduous forest types. Deciduousness is the associate adaptive strategy of those forests because of the prolonged dry season, slope and aspects (Singh and Kushwaha, 2016) and species composition vary with seasonality, rainfall, altitude and level of disturbance (Reddy et al. 2008).

Tropical deciduous forests are the foremost vul- 
nerable ecosystems in India, because of economic exploitation (Reddy et al., 2008) and recurrence of seasonal fire (Verma and Jayakumar, 2015). Notably, the dry deciduous forests are more susceptible to fire, that accounts more than $40 \%$ of all the forest types in India (Wikramanayake et al., 1998; Rodgers et al., 2002; Hiremath and Sundaram, 2005; Krishna and Reddy, 2012; Naveenkumar et al., 2017). In recent years, Western Ghats deciduous forest fire recurrence interval has inflated over 100 years, and therefore now the average recurrence interval is 3.3 years (Kodandapani et al., 2004).

The impact of human disturbance and recurrence of forest fire is continuing for many years, then the primary deciduous forests will be degraded into savanna-woodlands and open scrublands (Saha, 2003) with a regressive alteration of tree communities to grass dominance (Freson et al., 1974; Misra, 1983; Murphy and Lugo, 1986; Puyravud et al., 1994; Roth, 1999). It envisages a simplification of a climax to the degraded community with a loss of species diversity, canopy cover and a decline in vegetation (Saha, 2003).

The woody plant inventories in Western Ghats have been studied by several researchers (Ramesh and Pascal, 1991; Pascal and Pelissier, 1996; Parthasarathy, 1999; Ayyappan and Parthasarathy, 1999; Swamy et al., 2000; Sundarapandian and Swamy, 2000; Sundarapandian and Karoor, 2013; Sathiset al., 2013; Mohandas et al., 2016). However, the inventories on deciduous forest ecosystem are inadequate except few studies (Kothandaraman and Sundarapandian, 2017, Verma and Jayakumar, 2015; Padmakumar et al., 2018). Therefore, it is further stressed that there is an urgent need for quantitative inventory in the deciduous forest ecosystem. The primary aim of the study was to evaluate quantitative changes in diversity in different tropical forest types at the various elevations in Megamalai Wildlife Sanctuary, southern Western Ghats. The present study is a part of the largescale inventory i.e, quantitative inventory of trees in Suruli falls deciduous forest ecosystems, Southern Western Ghats.

\section{MATERIALS AND METHODS}

The present investigation was carried out at Suruli falls forest of Megamalai Wildlife Sanctuary, southern Western Ghats. The study sites are in the Cumbum forest range of Theni district Tamil Nadu and the dry deciduous forest (DDF) site located at $9^{\circ} 39^{\prime} 23.98 \prime \prime N \& 77^{\circ} 18^{\prime} 15.0^{\prime \prime} \mathrm{E}$, and the moist deciduous forest (MDF) site located at 9'39'14.08" N \& $77^{\circ} 19^{\prime} 6.59^{\prime \prime} \mathrm{E}$. The annual rainfall varied between $500-900 \mathrm{~mm}$. Forest is classified into southern Tropical Dry Deciduous forests and southern Tropical Moist Deciduous forest (Champion and Seth, 1968).
Two tropical deciduous forests namely dry deciduous forest (DDF) and moist deciduous forest (MDF) were selected (Fig. 1, Contour line map prepared and marked the study sites by using freely downloadable QGIS software, https:// qgis.org/en/site/forusers/ download.html). They varied in their terrain characteristics MDF is located at a higher elevation $(670 \mathrm{~m} \mathrm{msl})$ than DDF $(420 \mathrm{~m} \mathrm{msl})$. Both the sites are located in the Megamali Wildlife Sanctuary. Both the study site are far away from human settlements. DDF is subjected to recurrence of seasonal fire.

Two one-hectare square plots of $100 \mathrm{~m} \times 100 \mathrm{~m}$ were laid, one in each forest type. This was further sub-gridded into $10 \mathrm{~m} \times 10 \mathrm{~m}$ workable units. All living tree $(>10 \mathrm{~cm} \mathrm{DBH})$ individuals were enumerated and their girth was measured at breast height $(1.37 \mathrm{~m})$. Density, basal area, frequency, importance value index (IVI) and family importance value (FIV) were calculated. The distribution pattern of tree species was calculated by abundance to frequency method (A/F; Curtis and Cotton, 1956). Diversity indices were computed using Past 3.1 software (version 3.1; Øyvind Hammer, Natural History Museum, University of Oslo).

\section{RESULTS}

In tropical deciduous forest sites of Suruli falls region, overall 52 tree species were enumerated that were belonged to 35 genera and 21 families (Table 1). The distribution of species richness was more in MDF- moist deciduous forest (39 species) than DDF-dry deciduous forest (34 species). A similar pattern was observed in the case of stem density and basal area is concerned. Shannon's index, Alpha diversity and evenness index showed greater values in DDF, whereas dominance index showed greater values in MDF (Table 1).

The most speciose families in both the studied sites were Fabaceae (10) followed by Rubiaceae (5), Rhamnaceae (4), Ebenaceae (3), Moraceae (3) and Sapindaceae (3). The predominant family Fabaceae alone contributed $32 \%$ in terms of cumulative tree density of both the study sites followed by Combretaceae $17 \%$ and Loganiaceae $12 \%$. In DDF, Verbenaceae (57 in abundance) was the dominant family in terms of density even though Fabaceae (7 species) and Rubiaceae (4 species) were dominated at the species level. However, Fabaceae was the dominant family in terms of richness as well as density in MDF. Both the forest sites shared 16 common families of which two families (Annonaceae and Hernandiaceae) were only confined to DDF and three families (Apocynaceae, Ebenaceae and Meliaceae) were vested only with MDF (Table 2). As per botanical genera, the maximum members (28) were found in DDF and 27 members were enumerated from the MDF. Contrarily, the highest tree species richness (39) was observed in the MDF and the 


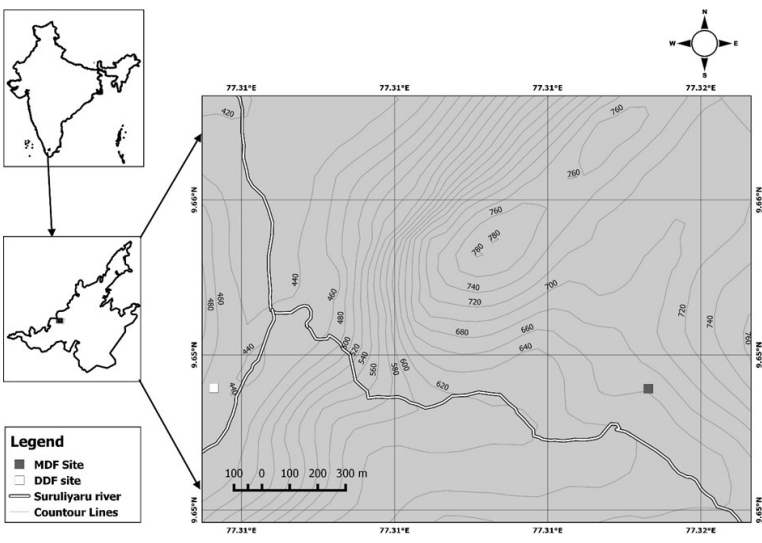

Fig. 1. Location of the study plots in Tropical deciduous forest of Suruli falls forest, Southern Western Ghats.
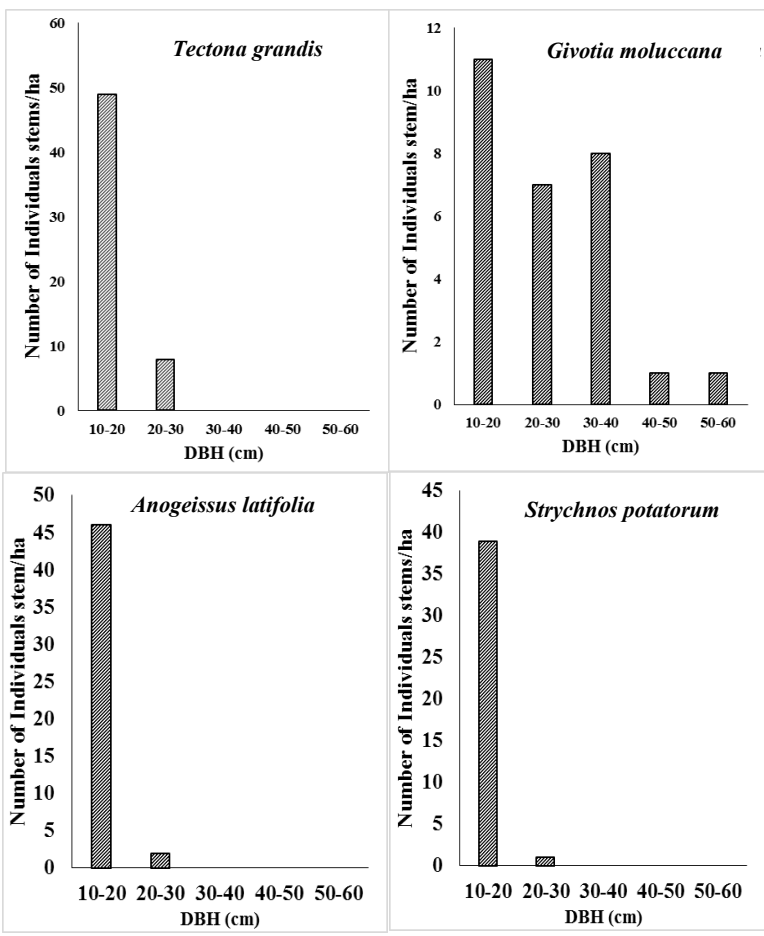

Fig. 3. Diameter class distribution of dominant tree species in tropical dry deciduous forest of Suruli falls, Southern Western Ghats.

lowest species richness (34) was found in the DDF (Tables 2 and 3).

A total of 777 tree $(\geq 10 \mathrm{~cm} \mathrm{DBH})$ individuals were enumerated in both the sites, of which MDF harboured 502 individuals, while DDF had 275 individuals. Similarly, the basal area of both study sites was $23.75 \mathrm{~m}^{2}$ and it increased with an increase in abundance. The basal area of MDF (16.52 $\mathrm{m}^{2} / \mathrm{ha}$ ) was two times higher than DDF (7.23 $\mathrm{m}^{2} / \mathrm{ha}$ ) (Table 1). Pterocarpus marsupium was the only mono-dominant species in MDF which accounted for $27 \%$ of the total stem density and $30 \%$ of the total basal area in both the sites. The site DDF was dominated by Tectona grandis (IVI) and followed by Givotia moluccana, Anogeis-

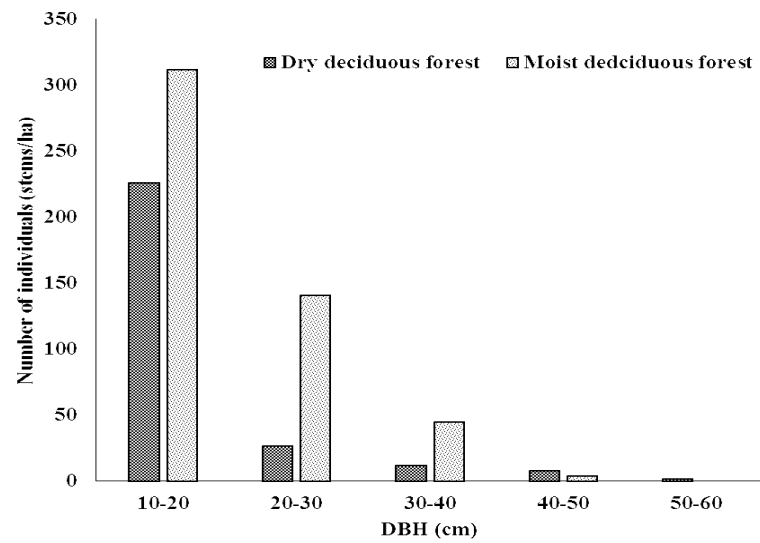

Fig. 2. Diameter class wise distribution of tree species in tropical deciduous forest of Suruli falls, Southern Western Ghats.
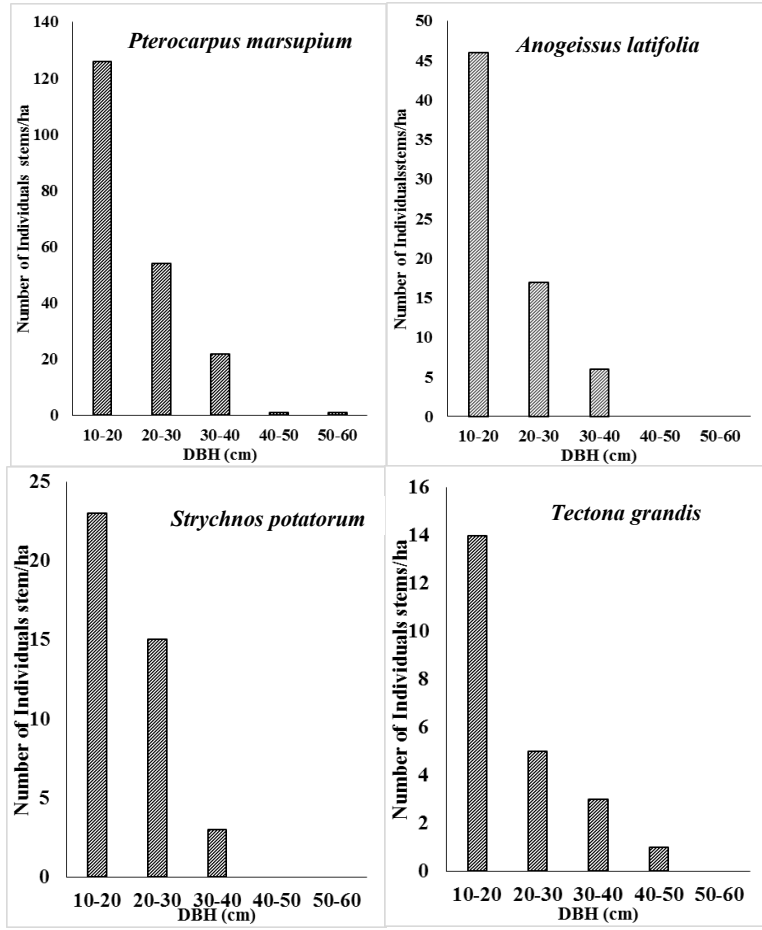

Fig. 4. Diameter class distribution of dominant tree species in tropical moist deciduous forest of Suruli falls, Southern Western Ghats.

sus latifolia and Strychnos potatorum whereas, $P$. marsupium (IVI) was the dominant species in MDF followed by $A$. latifolia, S. potatorum and G. moIuccana (Table 3). Interestingly in both sites, eleven species had only one individual. Overall twentyone species were common to both the sites and 13 species were confined to DDF and 18 species were restricted to MDF alone.

Diameter class distribution of trees $(\geq 10 \mathrm{~cm} \mathrm{DBH})$ showed abundance of trees decreases with increasing size class in both the study sites (Fig. 2). Maximum numbers of individuals were restricted to lower diameter class $(10-30 \mathrm{~cm})$. Distribution of dominant species were also showed similar pattern except for G. moluccana (Fig. 3 and 4). Forty- 
Table 1. Consolidated details of Tree species in Tropical deciduous forest of Suruli falls forest, Southern Western Ghats.

\begin{tabular}{lll}
\hline Characteristics & Dry Deciduous Forest & Moist Deciduous Forest \\
\hline Total no of Species (No./ha) & 34 & 39 \\
Genera & 28 & 27 \\
Family & 18 & 19 \\
Density (Stems/ha) & 275 & 502 \\
Basal Area (m²/ha) & 7.23 & 16.52 \\
Shannon's index & 2.652 & 2.378 \\
Evenness index & 0.4173 & 0.2765 \\
Dominance index & 0.11 & 0.20 \\
Fishers Alpha & 10.21 & 9.879 \\
\hline
\end{tabular}

Table 2. Family Contribution of Genera, species richness and density (No/ha) tree species in Tropical deciduous forest of Suruli falls forest, Southern Western Ghats.

\begin{tabular}{|c|c|c|c|c|c|c|}
\hline \multirow{2}{*}{ Family } & \multicolumn{3}{|c|}{ Dry Deciduous Forest } & \multicolumn{3}{|c|}{ Moist Deciduous Forest } \\
\hline & Genera & Species & Density & Genera & Species & Density \\
\hline Anacardiaceae & 1 & 1 & 2 & 1 & 1 & 2 \\
\hline Annonaceae & 1 & 1 & 1 & & & \\
\hline Apocynaceae & & & & 1 & 1 & 1 \\
\hline Bignoniaceae & 1 & 1 & 1 & 1 & 2 & 2 \\
\hline Burseraceae & 2 & 2 & 2 & 2 & 3 & 9 \\
\hline Caesalpiniaceae & & & & 1 & 1 & 5 \\
\hline Combretaceae & 2 & 2 & 61 & 2 & 2 & 71 \\
\hline Ebenaceae & & & & 1 & 3 & 22 \\
\hline Euphorbiaceae & 2 & 2 & 33 & 1 & 1 & 25 \\
\hline Fabaceae & 5 & 7 & 26 & 3 & 6 & 216 \\
\hline Hernandiaceae & 1 & 1 & 2 & & & \\
\hline Lamiaceae & 1 & 1 & 2 & 1 & 1 & 1 \\
\hline Loganiaceae & 1 & 1 & 40 & 1 & 2 & 50 \\
\hline Lythraceae & 1 & 1 & 2 & 1 & 1 & 4 \\
\hline Malvaceae & 1 & 2 & 4 & 1 & 1 & 8 \\
\hline Meliaceae & & & & 2 & 2 & 4 \\
\hline Moraceae & 1 & 2 & 3 & 1 & 1 & 1 \\
\hline Phyllanthaceae & 1 & 1 & 4 & 1 & 2 & 6 \\
\hline Rhamnaceae & 1 & 2 & 4 & 1 & 4 & 26 \\
\hline Rubiaceae & 3 & 4 & 19 & 2 & 2 & 14 \\
\hline Sapindaceae & 2 & 2 & 12 & 2 & 3 & 12 \\
\hline Verbenaceae & 1 & 1 & 57 & 1 & 1 & 23 \\
\hline
\end{tabular}

seven species were contagiously distributed and three were randomly distributed and two species were regularly distributed.

\section{DISCUSSION}

The tropical forest ecosystems are rich in biotic community worldwide. The species richness and abundance differ considerably among the tropics, particularly dry and moist tropical forests (Gentry, 1988; Naidu et al., 2018). High species richness is one of the characteristic features of the wet tropical ecosystem (Parsons and Cameron, 1947). The present study harboured high species richness in MDF-Moist deciduous forest (39 species) than that of DDF-Dry deciduous forest (34 species). Generally, tree species richness decreases with increase in altitude (Garibaldi and Linera, 2014), however, mid-altitude (approximately 600$1000 \mathrm{msl}$ ) has greater species richness than that of low and high altitude (Sundarapandian and Swamy, 2000; Reddy et al., 2011; Sundarapandian et al., 2015; Kanagaraj et al., 2017; Naveen- kumar et al., 2017; Kothandaraman and Sundarapandian, 2017). Our results support the findings of Murphy and Lugo (1986) who reported wet forests are more diverse than dry forests. The species variation between the two forest types in the present study was also influenced by moisture and elevation.

The species richness (>10 cm DBH) at onehectare scale is varied from across the tropical countries (20-307 species/ha, Campbell et al., 1992; Valencia et al. 1994) and also peninsular southern India (ranged from 4 species/ha, dry forest, Vindayan Hills, Eastern Ghats; Sagar et al., 2003 to 85 species/ha, wet forest KalakadMundanthurai, Western Ghats, Parthasarathy, 1999). The range value (34-39 species/ha) obtained from this study is comparable with other dry forests from (26-54/ha: Arulpragasan and Parthasarathy, 2010; 34-45/ha, Srinivas and Sundarapandian, 2018). However, the value is lower than findings of other parts of wet forest ecosystem, 65 species/ha in Varagalayar Anama- 
Naveenkumar, J. and Sundarapandian, SM. / J. Appl. \& Nat. Sci. 10 (4): 1085 -1093 (2018)

Table 3. Density (A), frequency (F), basal area (BA) and importance value index (IVI) of tree species in Tropical deciduous forest of Suruli falls forest, Southern Western Ghats.

\begin{tabular}{|c|c|c|c|c|c|c|c|c|}
\hline \multirow{2}{*}{ Species } & \multicolumn{4}{|c|}{ Dry Deciduous Forest } & \multicolumn{4}{|c|}{ Moist Deciduous Forest } \\
\hline & A & $\mathbf{F}$ & BA & IVI & $\mathbf{A}$ & $\mathbf{F}$ & BA & IVI \\
\hline Pterocarpus marsupium Roxb. & 4 & 4 & 0.11 & 4.98 & 204 & 77 & 6.98 & 107.86 \\
\hline $\begin{array}{l}\text { Anogeissus latifolia (Roxb. ex DC.) Wall. ex } \\
\text { Guill. \& Perr. }\end{array}$ & 48 & 32 & 0.61 & 42.02 & 69 & 47 & 2.03 & 40.90 \\
\hline Tectona grandis L.f. & 57 & 36 & 1.14 & 54.55 & 23 & 18 & 0.84 & 15.33 \\
\hline Givotia moluccana (L.) Sreem. & 28 & 23 & 1.83 & 47.10 & 25 & 18 & 0.78 & 15.37 \\
\hline Strychnos potatorum L.f. & 40 & 27 & 0.54 & 35.52 & 41 & 30 & 1.33 & 25.74 \\
\hline Terminalia elliptica Willd. & 13 & 11 & 1.08 & 25.20 & 2 & 2 & 0.07 & 1.44 \\
\hline Morinda pubescens J.E. Smith. & 11 & 9 & 0.25 & 11.94 & 10 & 9 & 0.45 & 7.55 \\
\hline Schleichera oleosa (Lour.) Oken & 8 & 3 & 0.13 & 6.15 & 9 & 8 & 0.45 & 7.07 \\
\hline Dalbergia lanceolaria ssp. lanceolaria L.f & 4 & 4 & 0.42 & 9.21 & 6 & 6 & 0.10 & 3.73 \\
\hline Ziziphus xylopyrus (Retz.) Willd. & 3 & 2 & 0.03 & 2.51 & 13 & 11 & 0.33 & 8.10 \\
\hline Diospyros Montana Roxb. & & & & & 15 & 12 & 0.02 & 6.93 \\
\hline Acacia catechu (L.f.) Willd. & 7 & 4 & 0.14 & 6.49 & & & & \\
\hline Grewia umbellate Roxb. & 1 & 1 & 0.02 & 1.10 & 8 & 7 & 0.25 & 5.29 \\
\hline Garuga pinnata Roxb. & 1 & 1 & 0.04 & 1.47 & 7 & 7 & 0.19 & 4.73 \\
\hline Strychnos nux-vomica L. & & & & & 9 & 7 & 0.33 & 5.98 \\
\hline Albizia odoratissima (L.f.) Willd. & 4 & 4 & 0.10 & 4.83 & 1 & 1 & 0.01 & 0.59 \\
\hline Cassia fistula L. & 5 & 3 & 0.15 & 5.38 & & & & \\
\hline Phyllanthus polyphyllus Willd. & 4 & 4 & 0.05 & 4.16 & 2 & 2 & 0.02 & 1.15 \\
\hline Mallotus philippensis (Lam.) Muell.Arg. & 5 & 5 & 0.06 & 5.11 & & & & \\
\hline Ziziphus glabrata Wight & 1 & 1 & 0.01 & 1.01 & 6 & 5 & 0.16 & 4.06 \\
\hline Diospyros melanoxylon Roxb. & & & & & 6 & 4 & 0.40 & 4.85 \\
\hline Ixora arborea Roxb. ex J. E. Sm. & 6 & 3 & 0.06 & 4.46 & & & & \\
\hline Lagerstroemia parviflora Roxb. & 2 & 1 & 0.02 & 1.52 & 4 & 3 & 0.18 & 2.83 \\
\hline Sapindus emarginatus Vahi. & 4 & 3 & 0.04 & 3.56 & 1 & 1 & 0.01 & 0.58 \\
\hline Lannea coromandelica (Houtt.) Merr. & 2 & 1 & 0.03 & 1.63 & 2 & 2 & 0.13 & 1.83 \\
\hline Commiphora caudata Engl. & 1 & 1 & 0.01 & 1.06 & 2 & 2 & 0.17 & 2.09 \\
\hline Grewia tiliaefolia Vahl. & 3 & 3 & 0.03 & 3.01 & & & & \\
\hline Bauhinia racemosa Lam. & & & & & 5 & 4 & 0.12 & 3.00 \\
\hline Ficus religiosa L. & 2 & 2 & 0.07 & 2.72 & & & & \\
\hline Gardenia latifolia Ait. & & & & & 4 & 4 & 0.11 & 2.72 \\
\hline Phyllanthus emblica L. & & & & & 4 & 4 & 0.08 & 2.57 \\
\hline Premna tomentosa Wild. & 2 & 2 & 0.05 & 2.47 & & & & \\
\hline Ziziphus rugosa Lam. & & & & & 4 & 3 & 0.10 & 2.36 \\
\hline Ficus mollis Vahl. & 1 & 1 & 0.11 & 2.34 & & & & \\
\hline Gyrocarpus americanus Jacq. & 2 & 2 & 0.04 & 2.26 & & & & \\
\hline Ziziphus jujube Mill. & & & & & 3 & 3 & 0.10 & 2.15 \\
\hline Albizia lebbeck (L.) Benth. & 1 & 1 & 0.03 & 1.27 & 1 & 1 & 0.04 & 0.75 \\
\hline Stereospermum colais DC. & 1 & 1 & 0.01 & 0.99 & 1 & 1 & 0.08 & 0.99 \\
\hline Ficus callosa Wild. & & & & & 1 & 1 & 0.24 & 1.95 \\
\hline Chukrasia tabularis A.Juss. & & & & & 3 & 3 & 0.06 & 1.92 \\
\hline Dalbergia pinnata (Lour.) Prain & & & & & 1 & 1 & 0.14 & 1.39 \\
\hline Dalbergia latifolia Roxb. & & & & & 3 & 2 & 0.01 & 1.31 \\
\hline Sapindus trifoliatus $\mathrm{L}$. & & & & & 2 & 2 & 0.02 & 1.16 \\
\hline Diospyros ovalifolia Wight & & & & & 1 & 1 & 0.09 & 1.08 \\
\hline Albizia amara (Roxb.) Boiv. & 1 & 1 & 0.01 & 1.03 & & & & \\
\hline Canthium parviflorum Lam. & 1 & 1 & 0.01 & 1.01 & & & & \\
\hline Canthium coromandelicum (Burm.f.) Alston & 1 & 1 & 0.01 & 0.97 & & & & \\
\hline Miliusa Montana ex Hook.f. and Thomson & 1 & 1 & 0.01 & 0.97 & & & & \\
\hline Stereospermum tetragonum DC. & & & & & 1 & 1 & 0.04 & 0.77 \\
\hline Wrightia tinctoria R.Br. & & & & & 1 & 1 & 0.02 & 0.66 \\
\hline Gmelina arborea Roxb. & & & & & 1 & 1 & 0.02 & 0.64 \\
\hline Aphanamixis polystachya (Wall.) R.Parker & & & & & 1 & 1 & 0.01 & 0.59 \\
\hline
\end{tabular}

lai (Ayyappan and Parthasarathy, 1999), 6-31 species (0.1ha) in Periyar Tiger Reserve Kerala (Sundarapandian and Karoor, 2013) and 56 species in Nilgiri (Mohandass et al., 2016). The variation in species composition, families and stand structure may be attributed to the location of the study sites, the surface area of the forest, microclimate, availability of water, intensity of grazing, the intensity of human activates etc., (Gandhi and Sundarapandian, 2014). However, total species 
richness of 52 species/2ha from this study is difficult to compare because of variation in plot dimension and methods employed (Apgaua et al., 2015).

Gentry (1988) noted that tropical forest ecosystems are mostly dominated by Leguminosae family members. The results from our study showed that Fabaceae was the most specious family in both the sites. Fabaceae is the sub-family of Leguminosae. The same Fabaceae family was dominant in some parts of Eastern Ghats (Gandhi and Sundarapandian, 2014; Sundarapandian et al., 2015; Kanagaraj et al., 2017). However, mostly Western Ghats forest ecosystem was dominated by Euphorbiaceae members (Ayyappan and Parthasarathy, 1999; Sundarapandian and Karoor, 2103; Sathish et al., 2013; Kothandaraman and Sundarapandian, 2017).

Murphy and Lugo (1986) suggested that the dry tropic forest basal cover ranged from $17-40 \mathrm{~m}^{2} / \mathrm{ha}$ and wet forest basal cover ranged from $20-75 \mathrm{~m}^{2}$ / ha. In the present study, both the plots have lesser than above range. Similarly, the basal area value is lower than values reported from other studies in India and elsewhere $\left(25.5 \mathrm{~m}^{2} / \mathrm{ha}\right.$, Campbell et al., 1992; 82.67m²/ha, Strasberg, 1996; $36.26 \mathrm{~m}^{2} /$ ha, Ayyappan and Parthasarathy, 1999; 21.50-47.30 $\mathrm{m}^{2} / \mathrm{ha}$, Lal et al., 2015; 9.96-34.15 $\mathrm{m}^{2} / \mathrm{ha}$, Yadav, 2016; 17.45-37.70 $\mathrm{m}^{2} / \mathrm{ha}$, Naveenkumar et al., 2017; 13-28.42 $\mathrm{m}^{2} / \mathrm{ha}$,Naidu et al., 2018; $20.5-29.4 \mathrm{~m}^{2} / \mathrm{ha}$, Srinivas and Sundarapandian, 2018). This may be past intervention of this forest. However, the MDF (Higher elevation) site basal area value is higher than the DDF (Lower elevation) site. Similar results were also reported from the Eastern Ghats and Western Ghats (Swamy et al., 2000; Sundarapandian et al., 2015; Kothandaraman and Sundarapandian, 2017). The differences in the basal area may be attributed to species composition, the age of the trees and degree of disturbances (Sundarapandian and Swamy, 2000).

The average density of this study (389 stems/ha) and it's range from 275-502 stems/ha is well within the tropical forest range (276-905 stems/ha) reported by Ghate et al. (1998). The density value obtained from this study is comparable with several other studies of peninsular India (Ayyappan and Parthasarathy, 1999; Sundarapandian and Swamy, 2000; Arulparagasam and Parthasarathy, 2010; Sundarapandian and Karoor, 2013; Satish et al., 2013; Naveenkumar et al., 2017; Kothandaraman and Sundarapandian, 2017; Naidu et al., 2018). This results comparatively lower than other parts of India and elsewhere (Pascal and Pelissier, 1996; Kumar et al., 2010; Lal et al., 2015; Yadav, 2016; Srinivas and Sundarapandian, 2018). This may be due to site-specific characters like rainfall, temperature, edaphic conditions etc. The tropical forest holds a high value of Shannon index $\left(\mathrm{H}^{\prime}\right)$ and in India, it ranged from $0.83-4.0$ (Singh et al., 1984). In the present study, Shannon index value ranged $2.38-2.65$ lies within the above range and also closer to other Indian forests (Sundarapandian and Swamy, 2000; Sundarapandian and Karoor, 2013; Kothandaraman and Sundarapandian, 2017). However it is lower than other deciduous forests values obtained from various parts of India (3.66, Thakur and Khare, 2006; 3.39, Prakasha et al,. 2008; 3.84-4.86, Dash et al., 2009; 4.56-5.18, Reddy et al., 2011; 3.38, Sahu et al., 2012). Site MDF has higher dominance index value than DDF is may be subjected to single specific dominance exist in this MDF, Diversity index value higher in DDF than MDF is due to the high value of evenness index in DDF.

Considering the importance value index (IVI) $P$. marsupium was the dominant species (113) followed by $A$. latifolia (83), T. grandis (69), G. moluccana (62) and $S$. potatorum (61) in both sites. The dominant species in terms of density was $T$. grandis followed by $A$. latifolia and $S$. potatorum in DDF, but were only found in the lower diameter class and did not reach a larger size. P. marsupium was the dominant species holding 204 individuals in MDF, but it only shared 4 individuals in DDF. Verma and Jayakumar (2015) reported that the deciduous forest of Mudumalai was dominated by $P$. marsupium 150 years ago (Cleghorn, 1861) and slowly replaced by $A$. latifolia due to their fire tolerant mechanism. The DDF site is subjected to recurrence of seasonal forest fire due to their prevalent dry environment. A. latifolia and S. potatorum are more abundant in the fire affected area, which may be due to thick corky bark and re -sprouting mechanisms.

Mono-dominant forest occurs in Asian and American Tropics side by side with the mixed forest as well (Gentry, 1982). P. marsupium was the mono dominant species holding one-third of the IVI. Hart et al. (1989) suggested that single-dominance in the tropical forest due to major disturbance over a relatively longer period of time. However in India, several researchers are also observed the monodominance in tree community (Sundarapandian and Swamy, 2000; Gandhi and Sundarapandian, 2014).

The natural forest ecosystem is always contiguous distribution and it is reported by several others, (Odum, 1971; Armesto et al., 1986; Kour and Sharma, 2014; Sharma and Raina, 2018; Srinivas and Sundarapandian, 2018). This study also showed maximum species incontiguous distribution. This may be due to significant variance in the environment (Odum, 1971).

\section{Conclusion}

The tropical deciduous forest types of Suruli falls region considerably differs among themselves due to variations in elevation, slope, aspects, moisture, 
rainfall, temperature and edaphic characteristics. The tropical moist deciduous forest is the transitional vegetation type between semi-evergreen and dry deciduous forests (Reddy et al., 2008). However, these deciduous ecosystems are under vulnerable due to human disturbance (either damage to species or planting with monoculture) and seasonal fire. Therefore, the prolonged disturbance and frequent recurrence of annual fire lead to the degrading of primary forest to savanna woodland and open scrublands (Saha, 2003). Once the savanna woodland or scrublands will be created, then difficult recover the climax forest, it may be due to mono-species, grass community will suppress the other plant structures either by competition or fire. So protection of this deciduous forest ecosystem is necessary for the future maintenance of diversity as well as to increase carbon sink potential.

\section{ACKNOWLEDGEMENTS}

The authors thank the Forest Department of Theni, Tamil Nadu for granting permission to conduct this study. JN is grateful to University Grants Commission, Government of India for granting fellowship. We thank Dr. S. Karuppuswamy, Department of Botany, Madura college, Madurai for identification of plants.

\section{REFERENCES}

1. Apgaua, D.M.G., Pereira, D.G.S. and Santos, R.M. (2015). Floristic variation within Seasonally Dry Tropical Forests of the Caatinga Biogeographic Domain Brazil and its conservation implications. International Forestry Review - Special Issue: Global Dry Forests, 17(S2): 33-43. https:// doi.org/10.1505/146554815815834840

2. Armesto, J. J., Mitchell, J. D. and Villagran, C. (1986). A Comparison of Spatial Patterns of Trees in Some Tropical and Temperate Forests. Biotropica, 18(1): 1-11. https://www.jstor.org/stable/2388354

3. Arulpragasan, L. and Parthasarathy, N. (2010). Landscape-level tree diversity assessment in tropical forests of southern Eastern Ghats, India. Flora. 205: 728-737. https://doi.org/10.1016/j.flora.2010.04.011

4. Aye,Y.Y., Pampasit, S., Umponstira, C., Thanacharoenchanaphas, K. and Sasaki, N. (2014). Floristic composition diversity and stand structure of tropical forests in Popa Mountain Park. Journal of Environmental Protection, 5: 1588-1602.http://dx.doi.org/10. 4236/jep.2014 .517150

5. Ayyappan, N. and Parthasarathy, N. (1999). Biodiversity inventory of trees in a large-scale permanent plot of tropical evergreen forest at Varagalaiar, Anamalais, Western Ghats, India. Biodiversity and Conservation. 8 (1): 1533-1554.

6. Campbell, D.G., Stone, J.L. and Rosas, J.A. (1992). A comparison of the phytosociology and dynamics of three floodplain (varzea) forest of known ages, Rio Jurua, western Brazilian Amazon. Botanical Journal of the Linnean Society, 108: 213-237. https:// doi.org/10.1111/j.1095-8339.1992.tb00240.x
7. Champion, H.G. and Seth, S.K. (1968). A Revised Survey of the Forest Types of India. Government of India, New Delhi.

8. Cleghorn, H.F.C. (1861). The Forests and Gardens of South India. WH Allen \& Company.

9. Curtis, J.T. and Cotton, G. (1956). Plant Ecology Workbook: Laboratory Field Reference Manual. Burgess Publishing Co, Minnesota.

10.Dash, P.K., Mohapatra, P.P. and Rao, G.Y. (2009). Diversity and distribution pattern of tree species $\mathrm{Ni}$ yamgiri hill Ranges, Orissa, India. The Indian Forester. 135(7):927-942.

11.Freson, R., Goffinet, G. and Malaise, F. (1974). Ecological effects of the regressive succession MuruluMiomboSavanna in upper Shaba (Zaire). Cave, A. J. (ed.), Proceeding First National Congress of Ecology, PUDOC, pp. 365- 371.

12.Gandhi, D.S. and Sundarapandian, S.M. (2014). Inventory of trees in tropical dry deciduous forests of Tiruvannamalai district, Tamil Nadu, India. Biodiversitas, 15 (2): 169-179. DOI: 10.13057/biodiv/d150208

13.Garibaldi, M.T. and Linera, G.M. (2014). Tree diversity patterns in successive vegetation types along an elevation gradient in the Mountains of Eastern Mexico. Ecological Research, 29: 1097-1104. https:// doi.org/10.1007/s11284-014-1196-4

14.Gentry, H.A. (1982). Patterns of neotropical plant species diversity. M. K. Hecht, B. Wallace \& G. T. Prance, editors. Evolutionary biology, Vol. 15, Plenum Press, New York, pp 1-84.

15.Gentry, H.A. (1988). Tree species richness of upper Amazonian forests. Proceedings of the National Academy of Sciences of the United States of America, 85:156-159. https://doi.org/10.1073/ pnas.85.1.156

16.Ghate, U., Joshi, N.V. and Gadgil, M. (1998). On the patterns of tree diversity in the Western Ghats of India. Current Science, 75: 594-603. https:// www.jstor.org/stable/24100563

17. Hart, T.B., Hart, J.A. and Murphy, P.G. (1989). Mono -dominant and species-rich forests in the humid tropics: causes for their co-occurrence. The American Naturalist, 133: 613-633. https://www.jstor.org/ stable/2462071

18. Hiremath, A.J. and Sundaram, B., (2005). The firelantana cycle hypothesis in Indian forests. Conservation and Society. 3(1): 26.

19. Hubbell, S.P. and Foster, R.B. (1992). Short-term dynamics of a neotropical forest: why ecological research matters to tropical conservation and management. Oikos, 63: 48-61. https://www.jstor.org/ stable/3545515

20.Kanagaraj, S., Selvaraj, M., Kangabam, R.D. and Munisamy, G. (2017). Assessment of tree species diversity and its distribution pattern in Pachamalai reserve forest, Tamil Nadu. Journal of Sustainable Forestry, 36(1): 32-46. https: // doi.org/10.1080/10549811.2016. 1238768

21.Karuppusamy, S and Ravichandran, V. (2016). Diversity Assessment of Woody Plants of Megamalai Wildlife Sanctuary, Theni District, Tamilnadu. Bio Bulletin. 2(1): 74-89.

22.Kaul, O.N, and Sharma, D.C. (1971). Forest type Statistics. Indian Forester. 97: 432-436.

23.Kodandapani, N., Cochrane, M.A. and Sukumar, R. (2004). Conservation threat of increasing fire frequencies in the Western Ghats, India. Conservation 
Biology, 18 (6): 1553-1561. DOI: 10.1111/j.15231739.2004.00433.x

24.Kothandaraman, S. and Sundarapandian, S.M. (2017). Structure of plant community in tropical deciduous forests of Kanyakumari Wildlife Sanctuary, India. Biodiversitas, 18(1): 391-400. https:// doi.org/10.1111/j.1523-1739.2004.00433.x

25.Kour, K. and Sharma, S. (2014). Diversity and phytosociological analysis of tree species in sacred groves of Vijaypur block, Samba (J\&K). International Journal of Science and Research. 3(6): 859-862.

26.Krishna, P.H. and Reddy, C.S. (2012). Assessment of increasing threat of forest fires in Rajasthan, India using multi-temporal remote sensing data (20052010). Current Science, 102(9). https://www.jstor.org/ stable/44721845

27.Krishnamurthy, Y.L., Prakasha, H.M., Nanda. A., Krishnappa, M., Dattaraja, H.S. and Suresh, H.S. (2010). Vegetation structure and floristic composition of a tropical dry deciduous forest in Bhadra Wildlife Sanctuary, Karnataka, India. Tropical Ecology. 51(2): 235-246.

28.Kumar J.I.N., Kumar, R.N., Bhoi1, R.K. and Sajish, P.R. (2010). Tree species diversity and soil nutrient status in three sites of tropical dry deciduous forest of western India. Tropical Ecology. 51(2): 273-279.

29.Lal, C., Singh, L., Attri, V. and Sarvade, S. (2015). Tree species diversity, distribution and population structure in a tropical dry deciduous forests of Chhatisgarh. India Journal of Applied and Natural Science, 7 (2): 681- 685. https://doi.org/10.31018/ jans.v7i2.666

30.Ledig, F.T. (1992). Human impact on genetic diversity in forest ecosystems. Oikos, 63: 87-108. https:// www.jstor.org/stable/3545518

31.Misra, R. (1983). Indian savanna. Bourliere, F. (ed.), Ecosystems of the world-tropical savannas. Elsevier, pp 151-166.

32.Mohandass, D., Hughes, A.C., Mackay, B., Davidar, P. and Chhabra, T. (2016). Floristic species composition and structure of a mid-elevation tropical montane evergreen forests (sholas) of the western ghats, southern India. Tropical Ecology. 57(3): 533-543.

33.Murphy, P.G. and Lugo, A.E. (1986). Ecology of dry tropical forest. Annual Review of Ecology Evolution and Systematics, 17: 67-88. https: //doi.org/10.1146/ annurev.es. 17.110186.000435

34.Naidu, M.T., Premavani, D., Suthari, S. and Venkaiah, M. (2018). Assessment of tree diversity in tropical deciduous forests of north central Eastern Ghats, India. Geology, Ecology and Landscapes, 2(3): 216227. https://doi.org/10.1080/24749508. 2018. 1452479

35.Nair, N.C. and Daniel, P. (1986). Floristic diversity of the Western Ghats and its conservation: a review. Proceeding of Indian Academy of Science Supplementary. 127-163.

36.Naveenkumar, J., Arunkumar, K. S. and Sundarapandian, SM. (2017). Biomass and carbon stocks of a tropical dry forest of the Javadi Hills, Eastern Ghats, India. Carbon Management, 8(56):351-361. https:// doi.org/10.1080/17583004.2017.1362946

37.Odum, E.P. (1971). Fundamentals of Ecology. 3rd ed. W.B. Saunders Company, Philadelphia.

38.Padmakumar, B., Sreekanth, N.P., Shanthiprabha, V., Paul, J., Sreedharan, K., Augustine, T., Jayasoor- yan, K.K., Rameshan, M., Mohan, M., Ramasamy, E.V. and Thomas, A.P. (2018). Tree biomass and carbon density estimation in the tropical dry forest of Southern Western Ghats, India. iForest,11: 534-541. doi: 10.3832/ifor2190-011

39.Parsons, R.F. and Cameron, D.S. (1974). Maximum plant species diversity in terrestrial communities. Biotropica, 6:202-203. https://www.jstor.org/ stable/2989653

40.Parthasarathy, N. (1999). Tree diversity and distribution in undisturbed and human-impacted sites of tropical wet evergreen forest in southern Western Ghats, India. Biodiversity and Conservation, 8:1365-1381. https://doi.org/10.1023/A:1008949407385

41.Pascal, J.P. and Pelissier, R. (1996). Structure and floristic composition of a tropical evergreen forest in south-west India. Journal of Tropical Ecology, 12: 191-214. https://www.jstor.org/stable/2560093

42.Poorter, L., van der Sande, M. T., Thompson, J., Arets, E. J. M. M. et al. (2015). Diversity enhances carbon storage in tropical forests. Global Ecology and Biogeography, 24:1314-1328. https://doi.org/10.1111/ geb.12364

43.Prakasha, H.M., Nanda, A. and Krishnamurthy, Y.L. (2008). Stand structure of a tropical dry deciduous forest in Bhadra wildlife sanctuary, Karnataka southern India, Bulletin of the National Institute of Ecology. 19: 1-7.

44.Puyravud, J. P., Pascal, J. P. and Dufour, C. (1994). Ecotone structure as an indicator of changing forestsavanna boundaries (Linganamakkl region, southern India). Journal of Biogeography. 21: 591-593. https:// www.jstor.org/stable/2846033

45.Ramesh, B.R. and Pascal, J.P. (1991). Distribution of endemic, arborescent evergreen species in the Western Ghats. Proceedings of the Symposium on Rare, Endangered and Endemic Plants of the Western Ghats. Kerala Forest Department, India. Kerala: Department of Forest, pp 20-29.

46.Reddy, C.S., Babar, S., Amarnath, G. and Pattanaik, C. (2011). Structure and floristic composition of tree stand in tropical forest in the Eastern Ghats of northern Andhra Pradesh, India. Journal of Forestry Research, 22(4): 491-500. DOI: 10.1007/s11676-0110193-5

47.Reddy, C.S., Ugle, P., Murthy, M.S.R. and Sudhakar, S. (2008). Quantitative Structure and Composition of Tropical Forests of Mudumalai Wildlife Sanctuary, Western Ghats, India. Taiwania, 53 (2): 150-156. DOI: 10.6165/tai2008.53(2).150

48.Rodgers, W.A., Panwar, H.S. and Mathur, V.B. (2002). Wildlife Protected Area Network in India, A Review: Executive Summary, Wildlife Institute of India, Dehradun, pp. 44.

49.Roth, L.C. (1999). Anthropogenic change in subtropical dry forest during a century of settlement in Jaiqui Picado, Santiago, Dominican Republic. Journal of Biogeography, 26:739-759. https://doi.org/10.1046/ j.1365-2699.1999.00328.x

50.Sagar, R., Raghubanshi, A.S., and Singh, J.S. (2003). Tree species composition, dispersion and diversity along a disturbance gradient in a dry tropical forest region of India. Forest Ecology and Management, 186: 61-71. https://doi.org/10.1016/S03781127(03)00235-4

51.Saha, S. (2003). Patterns in woody species diversity, richness and partitioning of diversity in forest commu- 
Naveenkumar, J. and Sundarapandian, SM. / J. Appl. \& Nat. Sci. 10 (4): 1085 -1093 (2018)

nities of tropical deciduous forest biome. Ecography, 26: 80-86. https://www.jstor.org/stable/3683528

52.Sahu., S.C., Dhal, N.K. and Mohanty, R.C. (2012). Tree species diversity, distribution and population structure in a tropical dry deciduous forest of Malyagiri Hill ranges, Eastern Ghats, India. Tropical Ecology. 53(2): 163- 168.

53.Sathish, B.N., Viswanath, S., Kushalappa C.G., Jagadish, M.R. and Ganeshaiah, K.N. (2013). Comparative assessment of floristic structure, diversity and regeneration status of tropical rainforests of Western Ghats of Karnataka, India. Journal of Applied and Natural Science, 5 (1): 157-164. https:// doi.org/10.31018/jans.v5i1.300

54.Sharma, J. and Raina A.K. (2018). Quantitative analysis, distributional pattern and species diversity of woody plant species of Lamberi Forest Range, Rajouri, J\&K, India. Journal of Applied and Natural Science, 10 (1): 522 - 527. https://doi.org/10.31018/ jans. v10i1.1661

55.Singh, J.S., Singh, S.P., Saxena, A.K. and Rawat, Y.S. (1984). India's Silent valley and its threatened rain forest ecosystem. Environmental Conservation, 11: 223- 233. https://doi.org/10.1017/ S0376892900014247

56.Singh, K.P. and Kushwaha, C.P. (2016). Deciduousness in tropical trees and its potential as indicator of climate change: A review. Ecological Indicators, 69: 699-706. j.ecolind.2016.04.011

57.Srinivas, K. and Sundarapandian, SM. (2018). Diversity, Population Structure and Distribution of Trees in Tropical Dry Forests, East Godavari District, Eastern Ghats, India. International Journal of Ecology \& Development. 33(2): 13-32.

58.Strasberg, D. (1996). Diversity, size composition and spatial aggregation among trees on a one-hectare rainforest plot at La Reunion. Biodiversity and Conservation, 5: 825-840. DOI: 10.1007/BF00054737

59.Sundarapandian, SM. and Karoor, P.J. (2013). Edge effects on plant diversity in tropical forest ecosystems at Periyar Wildlife sanctuary in the Western Ghats of India. Journal of Forestry Research, 24 (3): 403-418. https://doi.org/10.1007/s11676-013-0373-6
60.Sundarapandian, SM. and Swamy, P.S. (2000). Forest ecosystem structure and composition along the altitudinal gradient in the Western Ghats, South India. Journal of Tropical Forest Science, 12: 104-123. https://www.jstor.org/stable/23616407

61.Sundarapandian, SM., Naveenkumar, J, and Arunkumar, K.S. (2015). Tree diversity in tropical forest in the Javadi Hills in the Eastern Ghats India. Journal of Global Ecology and Environment. 3(4): 272-288.

62.Swamy, P.S., Sundarapandian, SM., Chandrasekar, P. and Chandrasekaran, S. (2000). Plant species diversity and tree population structure of a humid tropical forest in Tamil Nadu, India. Biodiversity and Conservation, 9: 1643-1669. https://doi.org/ 10.1023/ A: 1026511812878

63.Thakur, A.S. and Khare, P.K. (2006). Species diversity and dominance in tropical dry deciduous forest ecosystem. Journal of Environmental Research and Development. 1(1): 26-31.

64.Valencia, R., Balslev, H. and Paz Y Miño, C.G. (1994). High tree alpha-diversity in Amazonian Ecuador. Biodiversity and Conservation, 3(1): 21-28. https://doi.org/10.1007 /BF00115330

65.Verma, S. and Jayakumar, S. (2015). Post-fire regeneration dynamics of tree species in a tropical dry deciduous forest, Western Ghats, India. Forest Ecology and Management, 341: 75-82. https:// doi.org/10.1016/j.foreco.2015.01.005

66.Wikramanayake, E.D., Dinerstein, E., Robinson, J.G., Karanth, K.U., Rabinowitz, A., Olson, D., Mathew, T., Hedao, P., Conner, M., Hemley, G. and Bolze, D. (1998). An ecology-based method for defining priorities for large mammal conservation: the tiger as case study. Conservation Biology, 12: 865-878. https://doi.org/10.1111/j.1523-1739. 1998.96428.x

67.Wilson, E.O. (1988). The current state of biological diversity. In: Wilson, E.O. (Ed.). Biodiversity. The National Academic Press, Washington DC, pp 3-88.

68.Yadav. D. K. (2016). Species structure and diversity in Achanakmar-Amarkantak Biosphere Reserve, Central India. Journal of Applied and Natural Science, 8 (3): 1241 - 1248. https://journals. ansfoundation.org/index.php/jans/article/view/948 